\title{
PRODUCTIVE AND REPRODUCTIVE PERFORMANCE OF INDIGENOUS AND CROSSBRED CATTLE IN COMILLA DISTRICT
}

\author{
M. K. Uddin ${ }^{1}$, A. Wadud ${ }^{2}$, D. Begum ${ }^{3}$, M. S. R. Siddiki ${ }^{2}$ and M. H. Rashid ${ }^{2}$
}

\begin{abstract}
This study was conducted to compare the productive and reproductive performance of indigenous and crossbred cow likely Friesian, Sahiwal and Sindhi cross. A total of 180 dairy cows were selected randomly from four upazilas of Comilla district. It was observed that mean milk yield and lactation length of indigenous, Friesian cross, Sahiwal cross and Sindhi cross were $2.35 \pm 0.04,7.36 \pm 0.11,4.78 \pm 0.08$ and $4.03 \pm 0.05$ litre/day and $218.22 \pm 8.35,284.69 \pm 1.64$, $251.77 \pm 3.66$ and $259.77 \pm 4.91$ days respectively. It reveals that the Friesian cross is the best performer in relation to milk production and lactation length. About the reproductive performances it shows that indigenous cows need minimum (1.81 \pm 0.048$)$ services per conception. Gestation length was shorter in case of Sahiwal cross $(277.64 \pm 1.99$ days $)$ and it varies within Friesian and Sindhi cross in a short range (278.77 \pm 1.38 to $279.31 \pm 1.00$ days). Calving interval was lower in Friesian crosses (413.77 \pm 53.87 days) than its counterparts. Age at puberty was shorter in Friesian cross (662.44 \pm 2.52 days). It interprets that Friesian cross was the best performer than other crossbred and indigenous cows in dairy potentialities.
\end{abstract}

Key words : Indigenous, Crossbred, Productive, Reproductive, Dairy cows

\section{Introduction}

Bangladesh is a densely populated agriculture based country. Livestock is the existing smallholder subsistence agricultural situation of Bangladesh. The contribution of livestock in our national life plays vital role in the national income. Cattle provide us food as milk and meat, draft power, fuel and organic manure for soil. In spite of our large number of cattle population 25.5 million (BBS, 2003), the productions of milk are insufficient of our requirement. The production of cattle is low because of their poor genetic make up, about $90 \%$ of the total population are zebu type which are non-descriptive and indigenous in nature; large incidence of diseases always hamper their production. Usually they suffer in malnutrition, moreover hostile and stressful climatic condition fluctuate their production.

The demand for milk and milk products and meat i.e. animal protein is rapidly increasing day by day for the large number of population. Per capita availability of animal protein is about ten times less than the actual consumption (Alam, 1992). Most of the milk is produced by smallholder dairy farmers who have two or three cows which are reared for duel purposes like milk and draft power. Only few farmers have the cows for milk production. The average milk production of indigenous dairy cows is only 137 litres per lactation (DLS, 2003) whereas milk is considered as an ideal food for the people. That is why, at present the demand of crossbred cows are many times higher due to increased

\footnotetext{
${ }^{1}$ Deputy Co-ordinator, Youth Training Center, Department of Youth Development, Natore, Bangladesh

${ }^{2}$ Department of Dairy Science, Bangladesh Agricultural University, Mymensingh-2202, Bangladesh

${ }^{3}$ Senior Instructor (Livestock), Youth Training Center, Department of Youth Development, Natore, Bangladesh
}

(Received : July 23, 2008) 
Bang. J. Anim. Sci. 2008, 37 (1)

production of milk (ranges between 8-15 litres/day). It is remarkable that a reasonable number of small holder dairy farmers have found crossbred cows as a profitable business maintaining better nutrition, managements and diseases control. This study was conducted to compare the productive and reproductive performances of indigenous and crossbred dairy cows.

\section{Materials and Methods}

The study was conducted in Comilla district consists of four upazilas and these are Comilla sadar, Brahmanpara, Chaidhagram and Laksham. Numbers of farms taken from those upazilas were 20, 15, 15 and 5 respectively. A survey schedule was prepared before collecting data. Total 180 cows forty five from each of different breeds such as indigenous, Friesian cross, Sahiwal cross and Sindhi cross were collected from different location of the study area. The data were collected through direct interviewing from the farmers door to doors of the study area. To draw an accurate and reasonable date, care and cautions were take during data collection. The traits used to measures the productive and reproductive performances of indigenous and crossbred cows were milk yield (litre/d), Lactation length (days), gestation period (days), service per conception (No.), calving intervals (days) and age at puberty (days). Total milk yield can be estimated from the total lactation length in days. Lactation length was calculated from the date of let-down of milk after calving to the date of end of milking of a cow in days. Gestation period was measured in days from the date of successful insemination and date of calving. Service per conception is estimated by the average number of services for conception. The calving intervals were recorded on the basis of interval between the date of one calving to the date of next calving. The collected data were processed, tabulated and analyzed on Completely Randomize Design (CRD) and in case of significant difference Duncan's Multiple Range Test (DMRT) was done to find out the difference within each parameter according to Steel and Torrie (1980).

\section{Results and Discussion}

\section{Milk yield}

The average daily milk yield with standard error for different genetic group of cows are shown in Table 1.The highest milk yield was found in Friesian cross followed by Sahiwal, Sindhi cross and indigenous cows. It hampered due to the difference in the genetic make up of cows under study area (Table 1). The milk yield of different genetic group of cows differed significantly $(\mathrm{P}<0.001)$. This results shows the similarity to the study of Bhuiyan et al. (1992); Ali (1998).

\section{Lactation length}

The mean lactation length of various genetic group of dairy cows are shown in Table 1 and differed significantly $(\mathrm{P}<0.001)$. Lactation length was highest in Friesian cross and shortest in case of indigenous. For lactation length this variation occurs due to genetic differences. These results are more or less similar with the result of Bhuiyan and Sultana (1994).

\section{Gestation period}

The mean gestation period of various genetic group of dairy cows are shown in Table 1 and differed significantly $(\mathrm{P}<0.01)$. It appears that the shortest gestation period was found in Sahiwal cross cows (277.02 \pm 1.99 days) but highest value was found in indigenous dairy cows $(280.02 \pm 1.32$ days). Difference in gestation period might be attributed by genetic factor. Nahar et el., reported that the 
average gestation period of Sindhi, Sahiwal, Jersey and Holstein crossbred cows were 280.55, 279.81, 279.76 and 279.91 days respectively. Similar result was found by Mondal (1998).

Table 1. Different parameters of various genetic groups of cows

\begin{tabular}{|c|c|c|c|c|c|}
\hline \multirow{2}{*}{ Parameters } & \multicolumn{4}{|c|}{ Genetic groups } & \multirow{2}{*}{$\begin{array}{c}\text { Level of } \\
\text { significance }\end{array}$} \\
\hline & Indigenous & Friesian cross & Sahiwal cross & Sindhi cross & \\
\hline Daily milk yield (L/d) & $2.35^{\mathrm{d}} \pm 0.04$ & $7.36^{\mathrm{a}} \pm 0.11$ & $4.78^{\mathrm{b}} \pm 0.08$ & $4.03^{\mathrm{c}} \pm 0.05$ & $* *$ \\
\hline Lactation length (days) & $218.22^{\mathrm{c}} \pm 8.35$ & $284.69^{\mathrm{a}} \pm 1.64$ & $251.77^{b} \pm 3.66$ & $259.77^{\mathrm{b}} \pm 4.91$ & $* *$ \\
\hline Gestation period (days) & $280.02^{\mathrm{b}} \pm 1.32$ & $278.77^{\mathrm{ab}} \pm 1.38$ & $277.64^{\mathrm{a}} \pm 1.99$ & $279.31^{\mathrm{ab}} \pm 1.0084$ & $* *$ \\
\hline Service per conception(No.) & $1.81^{\mathrm{a}} \pm 0.048$ & $2.44^{\mathrm{b}} \pm 0.053$ & $2.13^{\mathrm{c}} \pm 0.037$ & $2.00^{\mathrm{b}} \pm 03043$ & $* *$ \\
\hline Calving interval (days) & $472.55^{\mathrm{c}} \pm 169.17$ & $413.77^{\mathrm{a}} \pm 53.87$ & $454.00^{\mathrm{b}} \pm 87.17$ & $459.33^{\mathrm{b}} \pm 87.68$ & $* *$ \\
\hline Age at puberty (days) & $725.11^{\mathrm{c}} \pm 7.74$ & $662.44^{\mathrm{a}} \pm 2.52$ & $712.55^{\mathrm{b}} \pm 2.24$ & $735.88^{\mathrm{d}} \pm 1.77$ & $* *$ \\
\hline
\end{tabular}

** Significant $(\mathrm{P}<0.01)$

${ }^{a b c d}$ Means with different superscripts $(\mathrm{s})$ in the same row differ significantly $(\mathrm{P}<0.01)$

\section{Service per conception}

The average number of service required per conception of various genetic groups of dairy cows are shown in Table 1 and differed significantly $(\mathrm{P}<0.001)$. The magnitude of service per conception was minimum in case of indigenous $(1.81 \pm 0.048)$ and maximum for Friesian cross $(2.44 \pm 0.053)$. (Jabbar and Ali (1988); Mondal (1998) findings was more or less similar of the present result. Variations in the service per conception might be due to failure to detect heat, improper insemination, low quality semen, failure to inseminate in the right time of heat period and in case of disease condition.

\section{Calving interval}

The mean calving interval of various genetic groups of dairy cows are shown in Table 1 and differed significantly $(\mathrm{P}<0.001)$. Among the different genetic group of cows the highest calving interval was found in Indigenous cows (472.55 \pm 169.27 days) but shortest record in Friesian cross $(413.77 \pm 53.87$ days). A part from heredity one of causes of long calving interval in Indigenous cows is that they were poorly fed and managed by low input farmers in contrast to that of Friesian cross. These results are in closer to the result of Nahar (1992). Calving interval vary due to the effect of genetic, nutritional, environmental and managemental condition.

\section{Age at puberty}

The average age at calving of various genetic group of dairy cows are shown in Table 1 and differed significantly $(\mathrm{P}<0.001)$. The average value was highest in Sindhi cross $(735.88 \pm 0.05$ days $)$ and shortest in Friesian cows (662.44 \pm 2.52 days). These results was more or less similar to the findings of Nahar et al. (1992); Ashraf (1998). The fluctuation in age at puberty might be due to genetic, nutritional, environmental effect and disease condition.

\section{Correlation between the parameters}

Indigenous cows shows that all correlation co-efficient were insignificant. It interprets that there is no effects on correlation between different traits of Indigenous cows. In case of Friesian cross it revealed that lactation length was found to be correlated $(\mathrm{P}<0.05)$ positively with daily milk yield and negatively with age at puberty. Other correlations co-efficient were insignificant. It implies that in 
Bang. J. Anim. Sci. 2008, 37 (1)

Friesian cross lactation length to some extent positively depends on daily milk yield but an increased age at puberty tended to reduce lactation length. For Sahiwal crosses, only correlations between age at puberty and lactation length and age at puberty and daily milk yield are positive and significant $(\mathrm{P}<0.05)$. It says that when age at puberty increases both lactation length and daily milk yield tended to increase. It suggests that an increase in the age at sexual maturity is not always discouraging. Again, in case of Sindhi cross the correlations between the lactation length and gestation period and calving interval and lactation length were positive $(\mathrm{P}<0.05)$. Results suggest that calving interval causes an increase in lactation length.

Table 2. Correlation between different traits of indigenous cows

\begin{tabular}{|l|c|c|c|c|}
\hline \multicolumn{1}{|c|}{ Parameters } & Gestation Period & Lactation length & Daily milk yield & Calving interval \\
\hline Lactation length & 0.110 & - & - & - \\
Daily milk yield & -0.141 & 0.191 & - & - \\
Calving interval & -0.143 & -0.053 & 0.095 & \\
Age at puberty & -0.050 & 0.062 & 0.134 & 0.098 \\
\hline
\end{tabular}

Table 3. Correlation between different traits of Friesian cows

\begin{tabular}{|l|c|c|c|c|}
\hline \multicolumn{1}{|c|}{ Parameters } & Gestation Period & Lactation length & Daily milk yield & Calving interval \\
\hline Lactation length & 0.200 & - & - & - \\
Daily milk yield & -0.103 & $0.210^{*}$ & - & - \\
Calving interval & -0.081 & -0.167 & -0.124 & \\
Age at puberty & 0.080 & $-0.222^{*}$ & 0.049 & -0.053 \\
\hline
\end{tabular}

* Non significant $(\mathrm{P}<0.05)$

Table 2 shows that all correlations co-efficient are insignificant. Table 3 shows that lactation length was found to be correlated $(\mathrm{P}<0.05)$ positively with daily milk yield and negatively with age at puberty. However, both correlation coefficients were of lesser degree. Other correlation coefficients were insignificant. It implies that in Friesian crosses lactation length to some extent positively depends on daily milk yield but increased age at puberty tended to reduce lactation length.

Table 4. Correlation between different traits of Sahiwal cows

\begin{tabular}{|l|c|c|c|c|}
\hline \multicolumn{1}{|c|}{ Parameters } & Gestation Period & Lactation length & Daily milk yield & Calving interval \\
\hline Lactation length & -0.190 & - & - & - \\
Daily milk yield & 0.180 & -0.212 & - & - \\
Calving interval & -0.137 & 0.091 & -0.186 & \\
Age at puberty & 0.191 & $0.286^{*}$ & $0.241^{*}$ & 0.135 \\
\hline
\end{tabular}

* Non significant $(\mathrm{P}<0.05)$

In Table 4, it is observed that correlations between age at puberty and lactation length and age at puberty and daily milk yield are positive and significant $(\mathrm{P}<0.05)$ in case of Sahiwal cross cows. It interprets that when age of sexual maturity increases both lactation length and daily milk yield tend to increase. It suggests that an increase in the age at sexual maturity is not always discouraging. 
In Table 5, it is showed that for Sindhi cross correlations between lactation length and gestation length and again calving interval and lactation length were positive $(\mathrm{P}<0.05)$. Results suggest that calving interval causes an increase in lactation.

Table 5. Correlation between different traits of Sindhi cows

\begin{tabular}{|l|c|c|c|c|}
\hline \multicolumn{1}{|c|}{ Parameters } & Gestation Period & Lactation length & Daily milk yield & Calving interval \\
\hline Lactation length & $0.247^{*}$ & & & \\
Daily milk yield & 0.156 & 0.044 & & \\
Calving interval & 0.028 & $0.215^{*}$ & -0.166 & \\
Age at puberty & -0.017 & 0.073 & 0.0745 & 0.153 \\
\hline
\end{tabular}

* Non significant $(\mathrm{P}<0.05)$

It may be concluded that Friesian crosses performed best while the indigenous one was worst. For valid judgment as to what type of cattle is to be reared in smallholder dairy farm of Bangladesh needs a comparative study including genetic, nutritional, managemental, socio-economical and ecological parameters.

\section{Literature Cited}

Alam, H. 1992. Studies of adoption of A. I. Technique in Bangladesh. Jahangirnagar Review Part A. Vol. 13-16.

Ashraf, A. 1998. A study on some economic traits of indigenous and graded cattle in Khulna region. M.S. Thesis, Department of Animal Breeding and Genetics. Bangladesh Agricultural University, Mymensingh.

BBS. 2003. Statistical Year Book on Bangladesh. Bangladesh Bureau of Statistics, Dhaka.

Bhuiyan, A. K. F. H. and Sultana, T. 1994. Analysis of performance of exotic cattle breeds and their crosses in Bangladesh. Proc. of the $5^{\text {th }}$ World Congress on Genetic Applied to Livestock Production, Held on 7-12 August 1994 in Guelph, Canada.20 : 355-358.

DLS, 2003. Annual Report of Department of Livestock Services (DLS), Ministry of Fisheries and Livestock, Dhaka, Bangladesh.

Jabbar, M. A. and Ali, I. Z. 1988. The limitation of cross breeding for improvement of cattle in Bangladesh. Oxford Agrarian Studies. 17 : 29-56.

Mondal, S. C. 1998. A comparative study on the productive performance of different dairy breeds of BAU Dairy Farm. M.S. Thesis, Department of Dairy Science, BAU, Mymensingh.

Nahar, T. N., Islam, M. and Hasanath, M. A. 1992. A comparative study on the performance of $F_{1}$ crossbred cows under rural conditions in and around the BAU campus. Asian-Australasian J. Anim. Sci. 5(3) : 435-438.

Steel, R. G. D. and Torrie, J. H. 1980. Principles and Procedures of Statistics. McGraw-Hill Book Company Inc., New York, USA. 